\title{
DEVELOPMENT OF A GARLIC BULB SEPARATOR: \\ 1. SEPARATING UNIT
}

M. M. IBRAHIM *

\section{ABSTRACT}

Garlic bulb separating is the unit operation through which cloves are separated to facilitate further processing. Conventional methods of clove separation are very laborious and time consuming. A garlic bulb separator was designed, fabricated and evaluated for its performance and techno-economic feasibility. Some physical and mechanical properties (dimensions, mass, volume, bulk density, angle of repose, static coefficient of friction and separation force) of garlic bulb that are pertinent to the mechanical processing were measured and considered by the design of the machine.

The developed machine was evaluated at three levels of cylinder speed $\left(C_{S}\right)\left(0.5,1.0\right.$ and $\left.1.5 \mathrm{~m} \mathrm{~s}^{-1}\right)$, three levels of concave clearance $\left(C_{C}\right)(20$, 25 and $30 \mathrm{~mm})$ and two levels of moisture content $\left(M_{C}\right)$ of garlic bulb (61.5\% and $70.3 \%$ w.b.). The evaluation was based on the following parameters: separation efficiency (SE), bulb damage (BD), machine capacity $\left(P_{m}\right)$, required power $(R P)$, consumed energy $(C E)$ and cost.

The results recommended operating the machine at combinations of $C_{S}=0.5$ to $1 \mathrm{~m} \mathrm{~s}^{-1}, C_{C}=20$ to $25 \mathrm{~mm}$ and $M_{C}$ value of $61.5 \%$ to maximum SE $(87.8 \%)$ with minimum BD $(5.3 \%)$. The garlic bulb separator increased the capacity to about 5.47 times and reduced the separating cost to about $69.23 \%$ comparing with manual method.

Keywords: Garlic, separator, design, efficiency, bulb damage.

\section{INTRODUCTION}

$\mathrm{G}$ Arlic (Allium sativum L.) has been used as a food, a condiment, and for medicinal purposes for many centuries. In Egypt, the garlic is grown each year, cultivated area is about $9674 \mathrm{Ha}$ and quantity of production was 244626 tons (FAOSTAT, 2010).

Garlic does not produce seeds, so it must be propagated vegetatively with garlic cloves as the most common planting material. The garlic production is affected by planting methods and clove rates and sizes (Nourai, 1994; Matlob and Khalel, 1986).

\footnotetext{
" Assist. Prof., Agric. Eng. Dept., Fac. of Agric., Cairo Univ.
} 
Before planting, bulbs must be separated into individual cloves. This must be done just prior to planting because separated cloves are more prone to disease and drying out if not stored well. Traditional separating methods do not support large-scale separating of garlic, especially for commercial purposes. Hand separating take a lot of time, even with some hand operated simple tools, therefore necessitated the design of low cost system that will be affordable and also increase separation efficiency but reduce the damage of the cloves.

The separator is one of the key components of garlic planting system. According to the agronomic requirement, the seed bulbs must be detached singly from the state of clusters in most of the production districts before planting (Iwasaki et al., 1992). This ensures that precision planting can provide accurate placement of single seed bulb at equal intervals within rows. The study on the physical and mechanical properties of garlic seed bulbs and related research achievements by Iwasaki et al.(1992) must be taken into account prior to any trails design garlic bulb separator.

Separation efficiency and seed bulb damage are mainly affected by the following factors (Srivastava et al., 2006): Cylinder diameter, spiketooth length of cylinder and concave, spike-tooth type, number of spiketeeth distributed in the helixes, cylinder rotary speed, clearance between cylinder and concave, seed bulbs feed rate, moisture content, maturity, and bulb type.

The objective of the present work was to design, fabricate and evaluate a low-cost separating unit for garlic bulbs that would combine safe impact velocities with appropriate clearances to maximize separation efficiency and minimize bulb damage.

\section{MATERIALS AND METHODS}

\subsection{Sample preparation}

Garlic bulbs (Egyptian Baladi variety) were randomly collected from different farms. Similar to local practice, the bulbs were dried by spreading in a thin-layer inside a darkroom with open windows near the farms for 15 days.

The moisture content of garlic bulb was determined by following ASAE S352.2 (ASAE, 1999) standard. Each sample weighing about $10 \mathrm{~g}$, were 
placed in a convection oven set at $130^{\circ} \mathrm{C}$ for $50 \mathrm{~min}$. The samples were, weighed and the moisture content was calculated and expressed in percent wet basis (w.b.). The moisture content values before and after drying were $70.3 \%$ and $61.5 \%$ respectively.

\subsection{Physical and mechanical properties of garlic bulb}

Some physical and mechanical properties of garlic bulb that are pertinent to the mechanical processing were measured and considered through the design stage of the machine.

\subsubsection{Dimensions, mass, volume and bulk density of garlic bulb}

Three axial dimensions (length, width, and thickness), mass and volume were measured, while bulk density of garlic bulb was calculated. The volume was measured by the volume of water displaced as a result of development of bulb is equal to the size of the bulb (the bulb coating by wax). The bulk density is the ratio of the mass of the sample to its container volume. It was measured by weighing a filled measuring cylinder with known volume and calculated according to Mohsenin (1986).

\subsubsection{Angle of repose}

The angle of repose indicates the cohesion among the individual units of a material. The higher the cohesion, higher is the angle of repose. The angle of repose of bulb garlic was measured in two ways: (1) the filling method, to determine the static angle of repose and (2) the emptying method, to determine the dynamic angle of repose. For the filling method, the sample was poured onto the cell through a fixed hopper in order to foster a constant feeding rate and thus the formation of a natural slope. The emptying method was determined by using an open-ended cylinder of $15 \mathrm{~cm}$ diameter and $50 \mathrm{~cm}$ height. The cylinder was placed at the centre of a circular plate having a diameter of $70 \mathrm{~cm}$ and filled with bulb. The cylinder was raised slowly until it formed a cone on the circular plate.

The angle of repose was calculated using the formula (Karababa, 2006):

$$
\theta=\tan ^{-1}\left(\frac{2 H}{d}\right)
$$


Where

$\theta \quad$ : Angle of repose, empty or filling (deg.).

$\mathrm{H} \quad$ : Height of the cone $(\mathrm{cm})$.

d : Diameter of the cone $(\mathrm{cm})$.

\subsubsection{Coefficient of static friction}

Coefficient of static friction is the ratio of force required to start sliding the sample over a surface divided by the normal force (Halling, 1975). The static coefficient of friction of bulb garlic against different materials, namely plywood, galvanized metal and rubber was determined at moisture content of $70.3 \%$. A device was used for the determination of the friction coefficient as shown in figure (1) according to Ibrahim (2008). The static coefficient of friction was calculated as follows:

$$
\mu=\frac{F_{T}-F_{E}}{W}
$$

Where

$\mu \quad$ : Coefficient of static friction.

$\mathrm{F}_{\mathrm{T}} \quad$ : Force required to start motion of filled wooden frame $(\mathrm{N})$.

$\mathrm{F}_{\mathrm{E}} \quad$ : Force required to start motion of empty wooden frame $(\mathrm{N})$.

W : Weight of the object $(\mathrm{N})$.

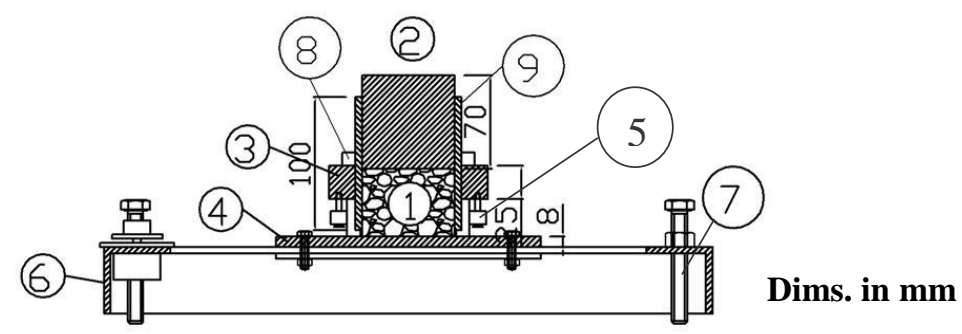

1-Sample

2- Piston

3- Carriage

4- Sliding surface

5- Rolling wheels

6- Base

7- Adjustable screw

8- Adjustable nut

9- Cylinder

Fig. (1): The device for measuring the friction force.

\subsubsection{Separating force}

It is defined as the force required for loosening the cloves from the bulb. The device that used for measuring friction was used to determine the separation force. The method was applied by placing one bulb between 
two plates (one lower and the other upper). The lower plate was covered by rubber material, and the upper plate was loaded, after the carriage was moved. This process was repeated with different loads until the cloves were loosened from the bulb without damage (Fig. 2). This process was performed at the different directions of the garlic bulb (length, width and thickness).

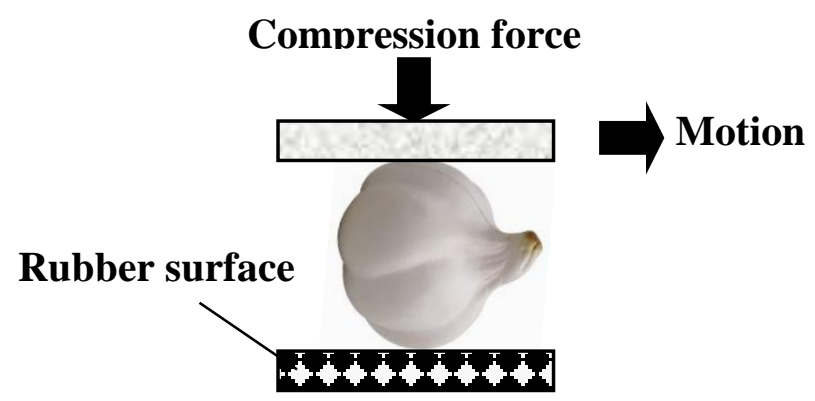

Fig. (2): Test method used for measuring separating force of bulb.

The physical and mechanical properties of the garlic bulb (Egyptian Baladi variety) that where utilized in designing of machine are presented in table (1).

Table (1): Some physical and mechanical properties of garlic bulb.

\begin{tabular}{llcccc}
\hline Property & & Min. & Max. & Mean & Stand. Dev. \\
\hline Length (mm) & 30.6 & 41.7 & 36.5 & 3.1 \\
Width (mm) & 39.9 & 71.9 & 51.4 & 6.8 \\
Thickness (mm) & 40.2 & 65.6 & 50.7 & 5.9 \\
Mass (g) & 87.6 & 45.3 & 62.5 & 11.6 \\
Volume (cm ) & & 30.6 & 41.7 & 36.5 & 3.1 \\
\multicolumn{2}{l}{ Bulk density $\left(\mathbf{g ~ c m}^{-3}\right)$} & 0.40 & 0.55 & 0.45 & 0.25 \\
\hline Angle of & Empty & 25.0 & 28.5 & 27.5 & 1.01 \\
repose (deg.) & Filling & 26.5 & 30 & 28.5 & 2.05 \\
\hline \multirow{2}{*}{ Coefficient of } & Metal & 0.28 & 0.70 & 0.42 & 0.09 \\
friction & Wood & 0.30 & 0.68 & 0.30 & 0.08 \\
& Rubber & 0.43 & 0.73 & 0.5 & 0.10 \\
\hline \multirow{2}{*}{ Separating } & Length & 193 & 270 & 123 & 8.8 \\
force (N) & Width & 183 & 245 & 221 & 7.8 \\
& Thickness & 179 & 237 & 197 & 4.8 \\
\hline
\end{tabular}




\subsection{Theoretical analysis approach}

It is important to have highest separation efficiency and simultaneously to minimize bulb damage in this design. Based on the comparative analysis of threshing mechanisms and its performance (Srivastava et al., 2006; CIGR, 1999), a tangential threshing mechanism was used.

Assumption that, hopper - It's shape aids discharge by gravity. The separation unit comprises of a cylinder supported by a shaft, which rotates against a stationary concave. Separating is achieved here by compression and shearing as shown in figure (3). As the material is forced to travel through by the aid of the rotation of the cylinder, it undergoes compression due to forces $\mathrm{F}_{\mathrm{C}}$ and $\mathrm{F}_{\mathrm{N}}$ generated by the cylinder against the bulb and subsequently undergoes shearing due to the forces $F_{1}$ and $F_{2}$. The compressive action separates the bulb, while the shearing force shears off the clove from bulb $\left(\mathrm{F}_{1}\right)$.

$$
\mathrm{F}_{1}=\mu \mathrm{F}_{\mathrm{C}}
$$

The total force required to separate bulb results from the effect of two main actions as shown in figure (3).

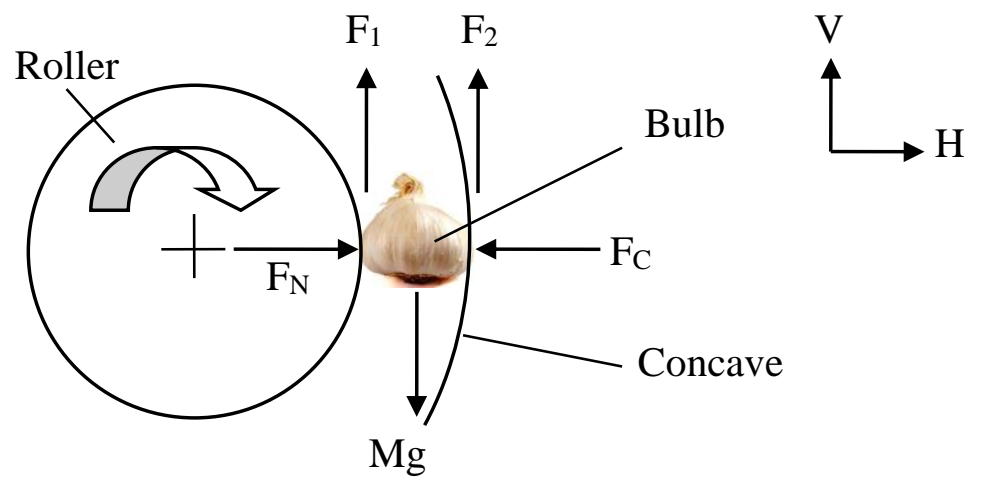

Fig. (3): Forces required to separate the bulb.

Assuming that at the point of separating, the bulb is momentarily stationary, then

$$
\begin{aligned}
& \text { Horizontal force, } F_{H}=0 \\
& \text { Therefore, } F_{N}-F_{C}=0 \\
& \text { So, } F_{N}=F_{C}
\end{aligned}
$$

So, $\mathrm{F}_{\mathrm{C}}$ compressive force equal to the force required for loosening the cloves from the bulb.

Also, vertical force, $\mathrm{Fv}=0$ or, $\mathrm{F}_{2}+\mathrm{F}_{1}-\mathrm{m}_{1} \mathrm{~g}=0$ 
Where

$\mathrm{m}_{1}$ : mass of bulb

Power needed for separating $\quad \mathrm{P}=\mathrm{F}$ V

Where

P : Power needed for separating (W).

F : Frictional force or shearing force $(\mathrm{N})$.

$\mathrm{V} \quad$ : $\quad$ Speed $=\mathrm{r} \omega\left(\mathrm{m} \mathrm{s}^{-1}\right)$.

$\mathrm{r}:$ : Radius of cylinder (m).

$\omega \quad: \quad$ Angular velocity of cylinder $=2 \Pi$ N/60 (radian).

$\mathrm{N} \quad$ : Cylinder speed (rpm).

\subsection{Design of machine components}

The design of developed machine has to be based on some important considerations such as:

1- Realizing reasonable production capacities to suit different sizes of garlic bulb.

2- Being simple and machine able.

3- Being easy to maintain and clean after working.

4- Reducing the fabrication costs by using standard components and local available materials.

5- Keeping the operating costs as low as possible.

The first step of the design of this machine is to calculate the power requirements of the machine as follows:

Compression force required to rubbing the one bulb $\left(\mathrm{F}_{\mathrm{N}}=\mathrm{F}_{\mathrm{C}}\right)$.

Shearing force required to rubbing $\left(\mathrm{F}_{1}\right)=\mu$. $\mathrm{F}_{\mathrm{C}}$.

Take $F_{C}$ equal $270 \mathrm{~N}$ (maximum separation force) and static coefficient of friction $(\mu)$ between bulb and rubber surface equal 0.73 (from table, 1). Therefore, $\quad F_{1}=0.73 \times 270=\mathbf{1 9 7 . 1}=\mathbf{2 0 0} \mathbf{~ N}$.

Total compression force $=$ No. of bulbs $\times$ required force for one bulb.

No. of bulbs that rubbing at simultaneously $=$ length of the concave / width of the bulb.

Length of the concave is $300 \mathrm{~mm}$ according to Arnold, (1964) and width of the bulb is $50 \mathrm{~mm}$ from table (1).

No. of bulbs $=300 / 50=6$ bulbs.

So, the total $F_{N}=F_{C}=270 \times 6 \quad=1620 \mathrm{~N}$.

Total shearing force $=1620 \times 0.73 \quad=1200 \mathrm{~N}$ 
According to Shigley (2008), the power delivered by a shaft due to separate the bulb is given by

$$
\mathrm{P}=\mathrm{F} \times \mathrm{V}
$$

The speed of cylinder is $1.5 \mathrm{~m} \mathrm{~s}^{-1}$ according to Chen et al. (2004).

Power for separating $=1200 \times 1.5=1800 \mathrm{~W}=\mathbf{1 . 8} \mathbf{~ k W}$.

The proposed design of the machine consists of the following main components as shown in Fig. (4): 1- Separating garlic cloves unit, 2Rotation shaft and bearings. 3- Power transmission unit. 4- Feeding unit. 5- Frame and support.

\subsubsection{Feeding unit}

The hopper was inclined $60^{\circ}$ to the horizontal based on the angle of repose of garlic bulbs to ensure self feeding and to avoid shattering losses through the feeding unit. The hopper and chute are constructed from (2 $\mathrm{mm}$ ) plate metal. The hopper is $600 \mathrm{~mm}$ length, $300 \mathrm{~mm}$ wide and 400 $\mathrm{mm}$ high. The hopper is trapezoidal in shape which is considered suitable for bulbs free falling.

\subsubsection{Frame and support}

The frame was manufactured locally from steel structures of angle-cross section (L2" $\times 2 " \times 1 / 8$ "). The dimensions of the frame are $120 \mathrm{~cm}$ length, $65 \mathrm{~cm}$ width, and $80 \mathrm{~cm}$ height. The frame includes two parts first part for supporting the motor and second part for supporting the machine.

\subsubsection{Power transmission unit}

A single phase electric motor with a rated speed of a $1440 \mathrm{rpm}$ and power of $3 \mathrm{hp}$, it has worm gear box to reduce the speed to $70 \mathrm{rpm}$.

Pulley size: V-belt was used because it is mostly common used, where a great amount of power is to be transmitted from one pulley to another. According to Khurmi and Gupta (2005):

$$
\mathrm{N}_{1} \mathrm{D}_{1}=\mathrm{N}_{2} \mathrm{D}_{2}
$$

Where

$\mathrm{N}_{1}, \mathrm{~N}_{2} \quad$ : $\quad$ Speed of driving and driven pulley respectively (rpm).

$\mathrm{D}_{1}, \mathrm{D}_{2} \quad$ : Diameter of driving and driven pulley respectively $(\mathrm{mm})$.

The machine will operate at three speeds: 50 (0.5), 100 (1) and $150 \mathrm{rpm}$ $\left(\mathrm{m} \mathrm{s}^{-1}\right)$. So, Substituting the required speeds at the separating unit $\left(\mathrm{N}_{1}\right.$ are 150, 100 and $50 \mathrm{rpm}$, the rated speed of the electric motor $\mathrm{N}_{2}$ was 70 $\mathrm{rpm}), \mathrm{D}_{1}$ and $\mathrm{D}_{2}$ where calculated as given in the table (2). 

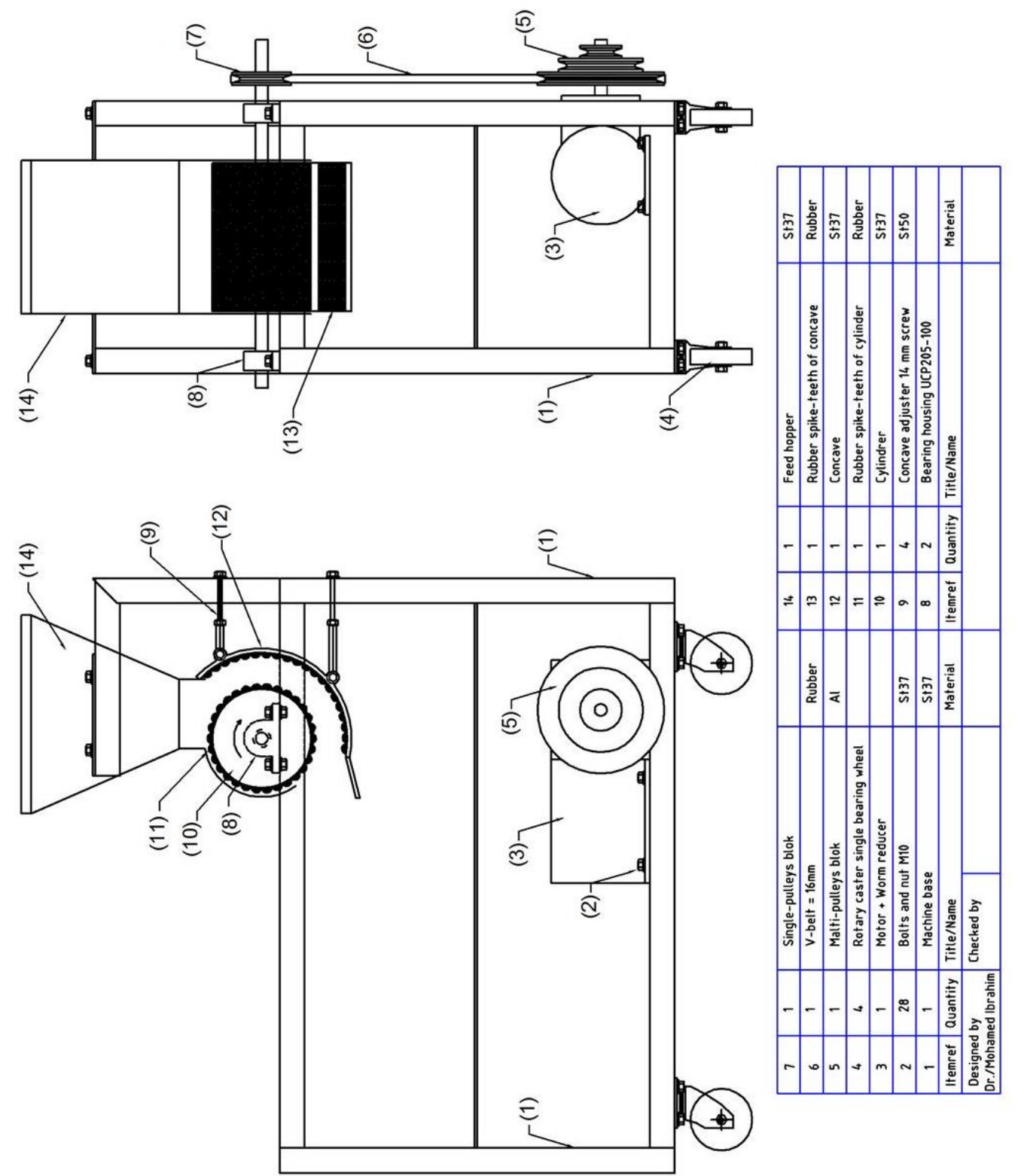

 
Table (2): Values of $D_{1}$ and $D_{2}$.

\begin{tabular}{lcccccc}
\hline & $\begin{array}{c}\text { Cylinder velocity } \\
\left(\mathrm{m} \mathrm{sec}^{-1}\right)\end{array}$ & \multicolumn{2}{c}{ Pulley of machine } & & \multicolumn{2}{c}{ Pulley of motor } \\
\cline { 3 - 4 } \cline { 6 - 7 } & $\mathrm{N}_{1}(\mathrm{rpm})$ & $\mathrm{D}_{1}(\mathrm{~mm})$ & & $\mathrm{N}_{2}(\mathrm{rpm})$ & $\mathrm{D}_{2}(\mathrm{~mm})$ \\
\hline $1 \mathrm{st}$ & 1.5 & 150 & 120 & & 70 & 257 \\
$2 \mathrm{nd}$ & 1 & 100 & 120 & & 70 & 171 \\
$3 \mathrm{rd}$ & 0.5 & 50 & 120 & & 70 & 85 \\
\hline
\end{tabular}

Length of belt $(\mathbf{L})$ : The length of the belt was calculated from the following equation:

$$
L=\frac{\pi}{2}\left(D_{1}+D_{2}\right)+2 x+\frac{\left(D_{1}-D_{2}\right)^{2}}{4 x}
$$

Where

$\mathrm{x}$ : Distance between centres of the two pulleys $(=60 \mathrm{~cm})$.

So, the belt length $(\mathrm{L})$ is $1.5 \mathrm{~m}$.

\subsubsection{Separation garlic cloves unit}

The separating unit consisted of a cylinder and a concave.

Separating cylinder - This was made up of a hollow pipe $5.0 \mathrm{~mm}$ thick, $300 \mathrm{~mm}$ long and $200 \mathrm{~mm}$ in diameter. By using standard rubber rollers (10 mm thick) fixed on the cylinder.

Concave: This is a stationary curved plate located beside the separation cylinder. The concave was constructed from a plate metal $5 \mathrm{~mm}$ thick to be able to withstand the impacts of bulb materials and $300 \mathrm{~mm}$ length. By using standard rubber rollers (10 mm thick) fixed on the cylinder. The concave clearance was changed by using four adjusted screws that were fixed on concave.

\subsubsection{Rotating shaft}

In order to transfer the power from the shaft, the various members (such as pulleys, bearings, and cylinder) are mounted on it. The shaft in this case is exposed to bending moment and torsional forces since it is utilized for torque transmission and bending moment (Fig. 5).

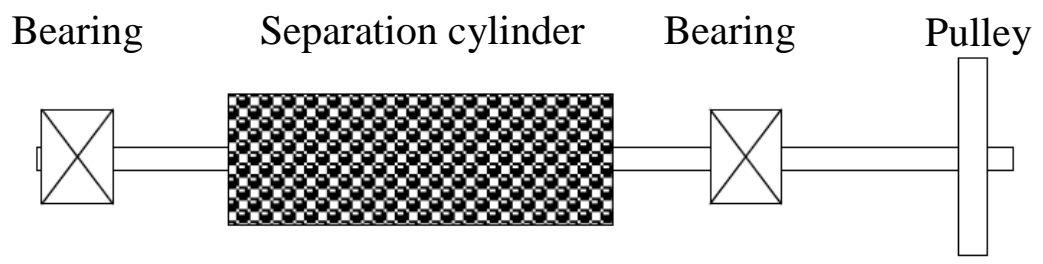

Fig. (5): Separation cylinder and shaft. 
Hence, the diameter of the shaft was calculated as follows (Eric, 1976):

$$
d^{3}=\frac{16}{\pi S_{s}} \sqrt{\left[K_{b} M_{b}\right]^{2}+\left[K_{t} M_{t}\right]^{2}}
$$

Where

d : Diameter of shaft (m).

$\mathrm{M}_{\mathrm{b}} \quad$ : Resultant bending moment (N-m).

$\mathrm{M}_{\mathrm{t}}$ : Torsional moment $(\mathrm{N}-\mathrm{m})$.

$\mathrm{K}_{\mathrm{b}}$ : Combined shock and fatigue factor applied to bending moment.

$\mathrm{K}_{\mathrm{t}}$ : Combined shock and fatigue factor applied to torsional moment.

Ss : Allowable shear stress of the shaft material $\left(\mathrm{MN}-\mathrm{m}^{-2}\right)$.

The values of $\mathrm{K}_{\mathrm{b}}$ and $\mathrm{K}_{\mathrm{t}}$ were taken as 1.5 and 1.0 respectively for the gradually applied load on the rotating shaft and the allowable shear stress of the shaft (Ss) as $40 \mathrm{MN}-\mathrm{m}^{-2}$ based on ASME code.

$\mathrm{M}_{\mathrm{b}}$ was calculated by analyzing moments due to both horizontal and vertical loading in bending moment diagrams of the shaft.

$\mathrm{M}_{\mathrm{t}}$ was calculated by the following equation:

$$
M_{t}=\frac{P \times 60}{2 \pi N}
$$

Using $\mathrm{P}=1800 \mathrm{~W}$ and $\mathrm{N}=150 \mathrm{rpm}, \mathrm{M}_{\mathrm{t}}$ was calculated as $114.59 \mathrm{~N}-\mathrm{m}$.

\section{For the cylinder}

Weight of cylinder $\left(\mathrm{W}_{\mathrm{C}}\right)=\rho \times \mathrm{Vc} \times \mathrm{g}$

Where

$\rho \quad: \quad$ Density of the material (for steel, $7860 \mathrm{~kg} \mathrm{~m}^{-3}$ ).

$\mathrm{V}_{\mathrm{C}} \quad$ : Volume of the cylinder.

$\mathrm{g}:$ : Acceleration due to gravity.

Volume of the cylinder $(\mathrm{Vc})=$ Volume of pipe + Volume of The two Circular plates.

Volume of pipe $\quad=\pi\left(\mathrm{r}_{\mathrm{o}}{ }^{2}-\mathrm{r}_{\mathrm{i}}{ }^{2}\right) \times \mathrm{h}$

Volume of the two circular plates $=2 \times \pi r_{o}{ }^{2} \times t_{h}$

Where

$\mathrm{r}_{\mathrm{o}}:$ : Outer diameter of the pipe $=100 \mathrm{~mm}$.

$\mathrm{r}_{\mathrm{i}} \quad$ : Inlet diameter of the pipe $=91 \mathrm{~mm}$.

h : Width of the cylinder $=300 \mathrm{~mm}$. 
$t_{\mathrm{h}}:$ Circular plate thick $=8 \mathrm{~mm}$.

So, the weight of cylinder $\left(\mathbf{W}_{\mathbf{C}}\right)=\mathbf{1 6 3 . 6 8} \mathrm{N}$.

Compression force extorted by concave and bulb on the cylinder $\left(\mathrm{F}_{\mathrm{N}}\right)=$ $1620 \mathrm{~N}$, this load acts at $25^{\circ}$ to the horizontal as shown in Fig. (6)

Resolving the load $\mathrm{F}_{\mathrm{N}}$ into vertical and horizontal components (Fig. 6), The vertical component $=\mathrm{F}_{\mathrm{N}} \sin 25^{\circ}=1620 \times \sin 25^{\circ} \quad \mathbf{= 6 8 4 . 6 4 \mathrm { N }}$ The horizontal component of $=\mathrm{F}_{\mathrm{N}} \cos 25^{\circ}=1620 \times \cos 25^{\circ}=1468.2 \mathrm{~N}$ Vertical loading $\left(\mathbf{F}_{\text {TV }}\right)$ on the shaft $=\mathrm{F}_{\mathrm{N}} \operatorname{Sin} 25+\mathrm{W}_{\mathrm{C}}=684.64+163.68=$ 828.9 $\mathbf{N}$, so distributed vertical loading $=828.9 / 0.5=\mathbf{1 6 5 7 . 8} \mathbf{N}-\mathbf{m}^{\mathbf{- 1}}$.

Horizontal loading $\left(\mathbf{F}_{\mathbf{T H}}\right)$ on the shaft $=\mathbf{1 4 6 8 . 2 2} \mathbf{N}$, so distributed vertical loading $=1468.22 / 0.5=\mathbf{2 9 3 6 . 4 4} \mathbf{N}-\mathbf{m}^{-1}$.

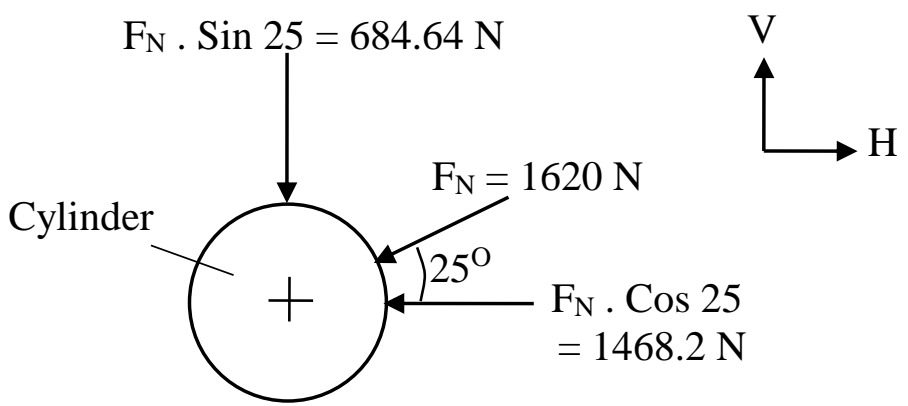

Fig. (6): The normal forces due to the separation.

\section{For the pulley:}

Weight of pulley $(\mathrm{Wp}) \quad=\mathrm{Vp} \times \rho_{\mathrm{p}} \times \mathrm{g}$

Where

Vp : Volume of the pulley in $\mathrm{m}^{3}(120 \mathrm{~mm}-$ diameter and $40 \mathrm{~mm}-$ thick)

$\rho_{p} \quad$ : Density of the pulley material (for aluminium $=2700 \mathrm{~kg} \mathrm{~m}^{-3}$ ).

So, $\mathrm{Wp}=11.98 \mathrm{~N}$

According to ASTM Standards, the V-belt is $16 \mathrm{~mm}$ that can transmit 2 $15 \mathrm{~kW}$.

Belt Force: The power transmitted by a belt drive is a function of the belt tensions and belt speed. The belt tensioning forces on the pulley was calculated according to the following equations (Khurmi and Gupta, 2005).

$$
\begin{aligned}
& 2.3 \log \mathrm{T}_{1} / \mathrm{T}_{2}=\mu \theta \operatorname{cosec} \beta \\
& \mathrm{Mt}=\left(\mathrm{T}_{1}-\mathrm{T}_{2}\right) \mathrm{R}_{1}
\end{aligned}
$$


Where

$\mathrm{T}_{1} \quad$ : Belt tension in tight side $(\mathrm{N})$.

$\mathrm{T}_{2}$ : Belt tension in loose side $(\mathrm{N})$.

$\mu \quad$ : Coefficient of friction between belt and pulley $(\mu=0.25)$.

$\theta \quad$ : Belt wrap angle $=(180-2 \alpha) \pi / 180$ (radian).

$\alpha \quad: \quad \sin \alpha=\frac{D_{1}+D_{2}}{2 x}$.

$2 \beta$ : Groove angle of the pulley $\left(32^{\circ}\right)$.

Mt : Torsional moment (N-m).

$\mathrm{R}_{1}$ : Radius of the machine pulley (m).

Torque transmitted by the pulley $(\mathrm{Mt})=\mathbf{1 1 4 . 5 9} \mathrm{N}-\mathrm{m}$. From the previous equations, $\mathrm{T}_{1}$ and $\mathrm{T}_{2}$ were calculated and are given in table (3):

Table (3): Values of $T_{1}$ and $T_{2}$.

\begin{tabular}{lllccccc}
\hline $\begin{array}{c}\mathbf{D}_{\mathbf{1}} \\
(\mathbf{m m})\end{array}$ & $\begin{array}{c}\mathbf{D}_{\mathbf{2}} \\
(\mathbf{m m})\end{array}$ & $\begin{array}{c}\boldsymbol{\alpha} \\
(\mathbf{d e g r e e})\end{array}$ & $\begin{array}{c}\boldsymbol{\theta} \\
(\mathbf{r a d i a n})\end{array}$ & $\begin{array}{c}\mathbf{T}_{\mathbf{1}} / \\
\mathbf{T}_{\mathbf{2}}\end{array}$ & $\begin{array}{c}\mathbf{T}_{\mathbf{1}} \\
(\mathbf{N})\end{array}$ & $\begin{array}{c}\mathbf{T}_{\mathbf{2}} \\
(\mathbf{N})\end{array}$ & $\begin{array}{c}\mathbf{T}_{\mathbf{1}}+\mathbf{T}_{\mathbf{2}} \\
(\mathbf{N})\end{array}$ \\
\hline 120 & 257 & 6.56 & 2.913 & 14.08 & 146.01 & 2022.84 & 2168.85 \\
120 & 171 & 2.44 & 3.056 & 16.04 & 126.98 & 2036.81 & 2163.79 \\
120 & 85 & $1-67$ & 3.083 & 16.43 & 123.77 & 2033.6 & 2157.37 \\
\hline
\end{tabular}

The maximum value of $\mathrm{T}_{1}+\mathrm{T}_{2}$ with $\mathrm{T}_{1}=146.01$ and $\mathrm{T}_{2}=2022.84 \mathrm{~N}$ was taken in the calculations. So, Total load acting on pulley $=\mathrm{T}_{1}+\mathrm{T}_{2}+\mathrm{Wp}=$ $2180.83 \mathrm{~N}$.

Accordingly, the shaft is subjected to vertical and horizontal loads of the values presented in table (4) and figure (7).

Table (4): Vertical and horizontal loads on the shaft.

\begin{tabular}{lcc}
\hline Type of load & At $(\mathbf{A})$ & At $(\mathbf{B})$ \\
\hline Vertical & $828.9 \mathrm{~N}\left(1657.8 \mathrm{~N}^{-1}\right)$ & 2180.83 \\
Horizontal & $1468.2 \mathrm{~N}\left(2936.4 \mathrm{~N}-\mathrm{m}^{-1}\right)$ & - \\
\hline
\end{tabular}

The maximum resultant bending moment $\left(\mathrm{M}_{\mathrm{b}}\right)$ and torsional moment $\left(\mathrm{M}_{\mathrm{t}}\right)$ were calculated and were found 109.04 and $114.59 \mathrm{~N}-\mathrm{m}$ respectively. By applying the calculated values of the different items in equation (8), shaft diameter should be equal or more than $30 \mathrm{~mm}$.

\subsubsection{Bearing selection}

The selection of a rolling bearing is made from a manufacturer's catalogue. By using FAG rolling bearing catalogue for the machine ball bearing was selected. 


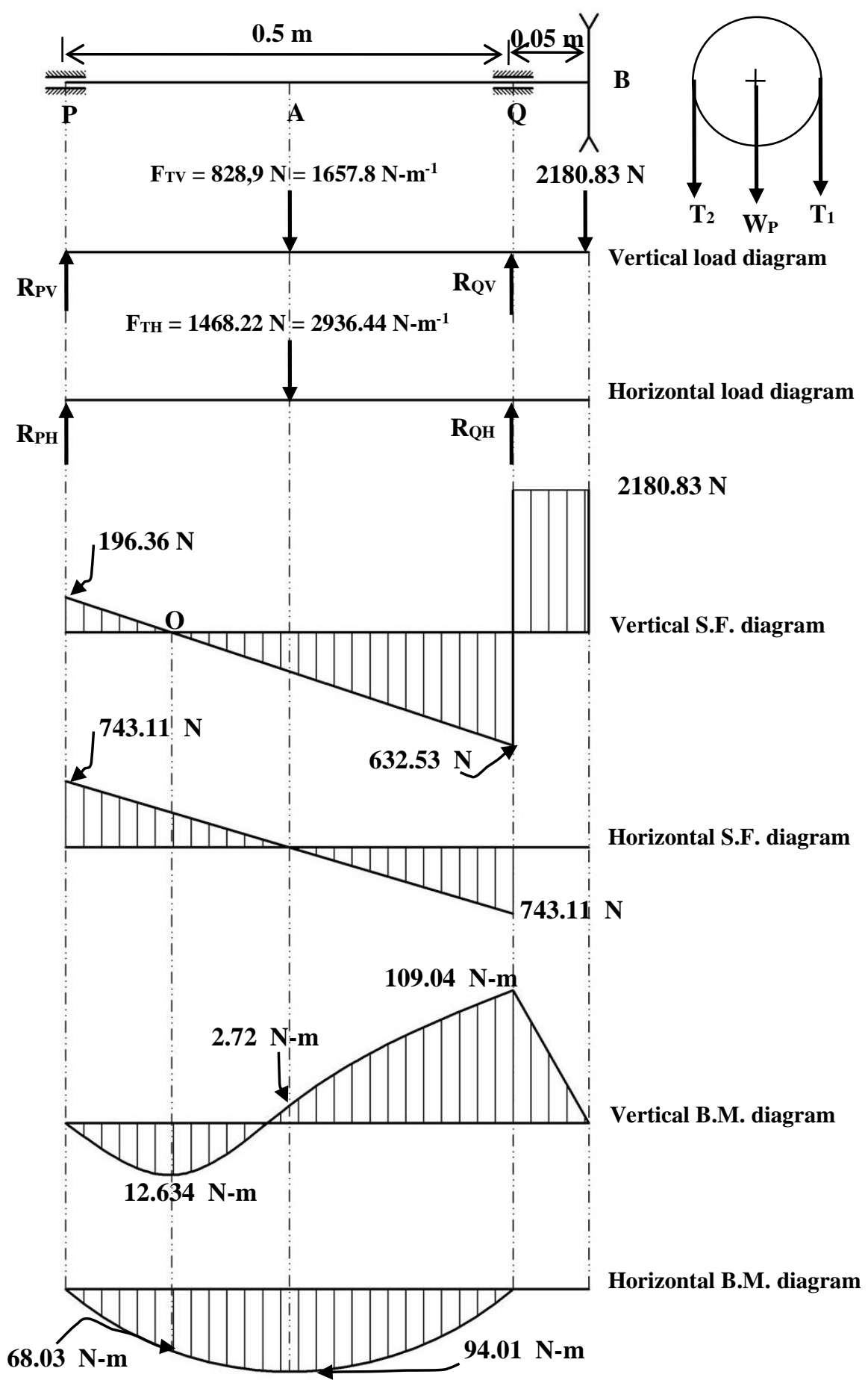

Fig. (7): The shearing and bending moment diagrams of the shaft. 


\subsection{Performance evaluation}

The development machine was evaluated at two different levels of moisture content of garlic bulb, three concave clearances and three levels of cylinder speed. According to literature data (ASAE-S343.3, 1999; Srivastava et al., 2006; CIGR, 1999), the performance of threshing mechanisms was possibly measured by threshing efficiency, separation efficiency, and grain damage. In reference to this information, the separation efficiency (its meaning is similar to the threshing efficiency), bulb damage percentage, machine capacity, required power and consumed energy were evaluated at each combination of variables.

During the test period, the speed of the main shaft was recorded using a tachometer. The levels of the variables for testing the machine are included in table (5).

Table (5): Experimental plan for evaluating the machine.

\begin{tabular}{ll}
\hline \multicolumn{1}{c}{ Variables } & Levels \\
\hline Bulb moisture content, $\mathrm{M}_{\mathrm{C}}(\%$ w.b). & $61.5,70.3$ \\
Concave clearance, $\mathrm{C}_{\mathrm{C}}(\mathrm{mm})$. & $20,25,30$ \\
Cylinder speed, $\mathrm{C}_{\mathrm{S}}, \mathrm{m} \mathrm{s}^{-1}(\mathrm{rpm})$ & $0.5(50), 1.0(100), 1.5(150)$ \\
\hline
\end{tabular}

\subsubsection{Machine capacity $\left(P_{m}\right)$}

Time of separating process was measured by means of a stop watch. The machine capacity was calculated as follows:

$$
\mathrm{P}_{\mathrm{m}}=\frac{\mathrm{W}}{\mathrm{T}}
$$

Where

$\mathrm{P}_{\mathrm{m}} \quad$ : The machine capacity $\left(\mathrm{kg} \mathrm{h}^{-1}\right)$.

W : The mass of sample $(\mathrm{kg})$.

$\mathrm{T}$ : Separating time (hour).

\subsubsection{Separation efficiency (SE)}

Separation efficiency is defined as the percentage of bulbs detached on the basis of the total clusters of bulbs fed into the separator. Separation efficiency (SE) was calculated according to the following equation:

$$
\mathrm{SE}(\%)=\frac{\text { Weight of separated bulb }(\mathrm{kg})}{\text { Total weight of bulb }(\mathrm{kg})} \times 100
$$




\subsubsection{Bulb damage (BD)}

Seed bulb damage refers to the mechanical damage to the bulbs during the separation process. Methods of measuring bulb damage include visual inspection in which the bulb scale appears broken to the naked eye (Srivastava et al., 2006). Bulb damage (BD) was calculated by the following equation:

$$
\mathrm{BD}(\%)=\frac{\text { Weight of damaged garlic cloves }(\mathrm{kg})}{\text { Total weight of sample }(\mathrm{kg})} \times 100
$$

\subsubsection{Required power (RP) and consumed energy (CE)}

The required electric power under machine working load (RP) was calculated as Chancellor (1981) by the following equation:

$$
\mathrm{RP}=\mathrm{V} \times \mathrm{I} \times \cos \theta
$$

Where

RP : The required power for separating bulb (W).

$\mathrm{V}:$ : Potential difference, Voltage (I phase $=220$ voltage).

I : : Line current strength (Amperes).

$\cos \theta \quad: \quad$ Power factor (0.64).

A digital clamp meter and Voltmeter were used for measuring current intensity and voltage respectively.

The consumed energy (CE) is specific power per unit capacity; it was calculated by using the following equation:

Consumed energy $=\left(\mathrm{P} / \mathrm{P}_{\mathrm{m}}\right), \quad \mathrm{kW} \mathrm{h}$ ton $^{-1}$

\subsubsection{Costs}

Machine cost was determined using the fixed costs and variable costs according to Srivastava et al. (2006), where the price of fabricated machine was 5000 L.E. The operational cost was determined using the following equation:

Oprating cost $=\frac{\text { Machine cost }\left(\mathrm{L} . E ~^{-1}\right)}{\text { Machine capacity }\left(\text { ton }^{-1}\right)}, \quad$ L.E ton ${ }^{-1}$ 


\section{RESULTS AND DISCUSSIONS}

Table (6) shows mean values of machine performance at different speeds, concave clearances and moisture contents.

Table (6): Performance parameter of machine at different moisture, cylinder speed and concave clearance.

\begin{tabular}{|c|c|c|c|c|c|c|}
\hline $\begin{array}{c}\text { Cylinder } \\
\text { speed } \\
\left(\mathrm{m} \mathrm{s}^{-1}\right)\end{array}$ & $\begin{array}{c}\text { Concave } \\
\text { clearance } \\
(\mathbf{m m})\end{array}$ & $\begin{array}{c}\text { Separation } \\
\text { efficiency } \\
(\%)\end{array}$ & $\begin{array}{c}\text { Bulb } \\
\text { damage } \\
(\%)\end{array}$ & $\begin{array}{l}\text { Machine } \\
\text { capacity } \\
\left(\mathbf{k g ~ h}^{-1}\right)\end{array}$ & $\begin{array}{c}\text { Required } \\
\text { power } \\
\text { (W) }\end{array}$ & $\begin{array}{c}\text { Consumed } \\
\text { energy } \\
\left(\mathbf{k W} \text { h ton }^{-1}\right)\end{array}$ \\
\hline & \multicolumn{6}{|c|}{$\begin{array}{c}\text { Moisture content }-61.5 \% \\
\end{array}$} \\
\hline \multirow{3}{*}{0.50} & 20 & 81.7 & 8.5 & 233.33 & 994 & 4.26 \\
\hline & 25 & 75.25 & 5.3 & 266.67 & 973 & 3.65 \\
\hline & 30 & 61.45 & 4.3 & 280.00 & 938 & 3.35 \\
\hline \multirow{3}{*}{1.00} & 20 & 87.80 & 10.7 & 326.92 & 1036 & 3.17 \\
\hline & 25 & 79.12 & 7.2 & 353.85 & 980 & 2.77 \\
\hline & 30 & 65.50 & 6.3 & 365.38 & 954.8 & 2.61 \\
\hline \multirow{3}{*}{1.50} & 20 & 90.33 & 18.2 & 402.86 & 1050 & 2.61 \\
\hline & 25 & 85.15 & 14.9 & 428.57 & 996.8 & 2.33 \\
\hline & 30 & 70.70 & 10 & 454.29 & 973 & 2.14 \\
\hline & \multicolumn{6}{|c|}{ Moisture content - $70.3 \%$} \\
\hline \multirow{3}{*}{0.50} & 20 & 75.43 & 7.14 & 240.00 & 1022 & 4.26 \\
\hline & 25 & 71.35 & 4.77 & 267.67 & 987 & 3.70 \\
\hline & 30 & 64.2 & 4.12 & 283.33 & 952 & 3.36 \\
\hline \multirow{3}{*}{1.00} & 20 & 82.6 & 9.1 & 336.54 & 1038.8 & 3.09 \\
\hline & 25 & 76.4 & 6.2 & 338.46 & 994 & 2.94 \\
\hline & 30 & 67.5 & 5.7 & 369.23 & 968.8 & 2.62 \\
\hline \multirow{3}{*}{1.50} & 20 & 85.14 & 14.9 & 407.14 & 1057 & 2.60 \\
\hline & 25 & 81 & 12.4 & 439.29 & 1015 & 2.31 \\
\hline & 30 & 70.3 & 8.5 & 460.71 & 994 & 2.16 \\
\hline
\end{tabular}

\subsection{Separation efficiency (SE)}

The separation efficiency ranged from $61.45 \%$ to $90.33 \%$ with cylinder speed of 0.5 to $1.5 \mathrm{~m} \mathrm{~s}^{-1}$, the concave clearance of 20 to $30 \mathrm{~mm}$ and moisture content of 61.5 to $70.3 \%$.

The results are plotted in Fig. 8. It could be noticed that the lowest values of separation efficiency were obtained at $0.5 \mathrm{~m} \mathrm{~s}^{-1}$, however the highest values of separation efficiency were obtained at $1.5 \mathrm{~m} \mathrm{~s}^{-1}$ at different concave clearances and moisture contents. As the cylinder speed increased the un-separated bulbs decreased. These results may be due to 
increasing the impact action of the cylinder on the bulb which is directly proportional with cylinder speed. Increasing the impact action due to increasing cylinder speed increased the kinetic energy of the bulb; consequently the bulbs will be quicker and run away from the cylinder. Therefore the separating efficiency will be increased.

At a given concave clearance and cylinder speed, the separation efficiency increases with decreasing in moisture content. This may be due to with increasing the moisture content the cloves become more adhesive to the bulb, so it is difficult to loose the cloves form the bulb.

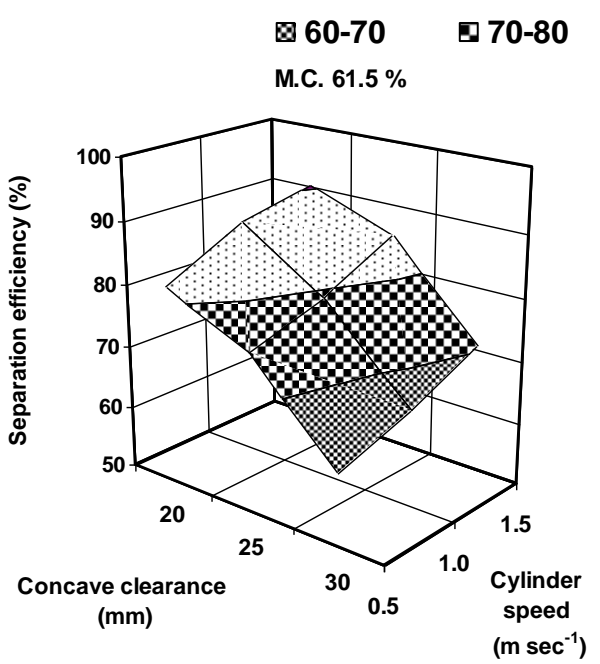

$\square 80-90 \square 90-100$

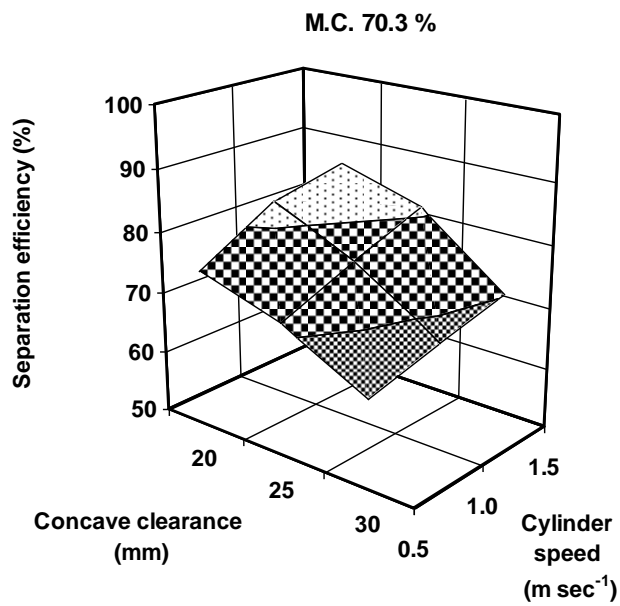

Fig. (8): The effects of cylinder speed, concave clearance and moisture content on the separation efficiency.

\subsection{Bulb damage (BD)}

The bulb damage ranged from $4.12 \%$ to $18.2 \%$ with cylinder speed of 0.5 to $1.5 \mathrm{~m} \mathrm{~s}^{-1}$, the concave clearance of 20 to $30 \mathrm{~mm}$ and moisture content of 61.5 to $70.3 \%$ (Table 6).

The bulb damage was influenced by the cylinder speed, concave clearance and moisture content. The bulb damage was the least at the lowest cylinder speed of $0.5 \mathrm{~m} \mathrm{~s}^{-1}$ and increased with increase in speed. Generally, the concave clearance of $30 \mathrm{~mm}$ caused the minimum bulb damage at a given moisture and speed. The bulb damage increased with reduction in concave clearance. The bulb damage increased with reduction in moisture content, as shown in figure (9). 


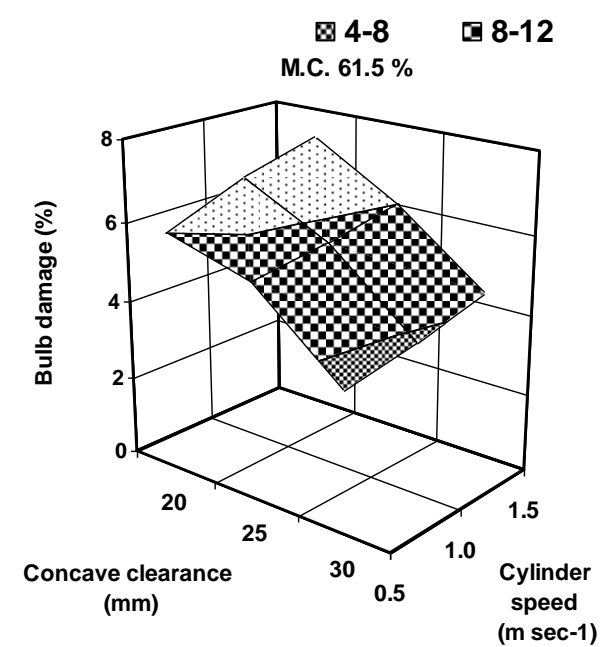

$\square$ 12-16 $\square \mathbf{1 6 - 2 0}$

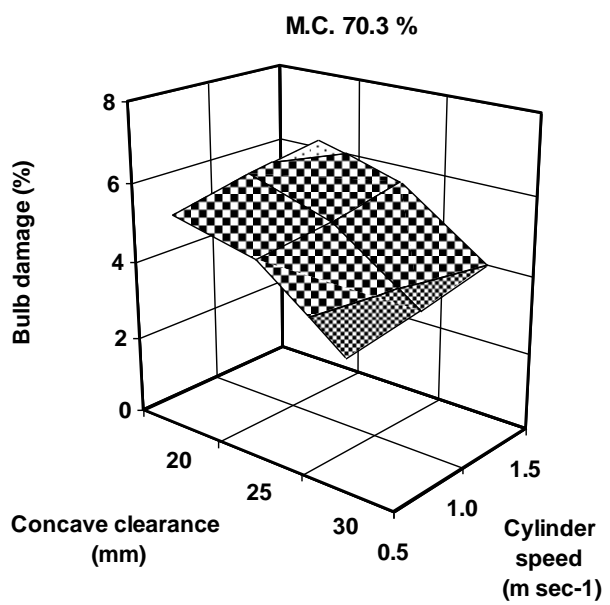

Fig. (9): The effects of cylinder speed, concave clearance and moisture content on bulb damage.

\subsection{Machine capacity $\left(\mathbf{P}_{\mathrm{m}}\right)$}

The machine capacity ranged from 233.33 to $460.71 \mathrm{~kg} \mathrm{~h}^{-1}$ with cylinder speed of 0.5 to $1.5 \mathrm{~m} \mathrm{~s}^{-1}$, the concave clearance of $20 \mathrm{~mm}$ to $30 \mathrm{~mm}$ and moisture content of 61.5 to $70.3 \%$ (Table 6). The machine capacity was influenced by the cylinder speed, concave clearance and moisture content.

The machine capacity was the least at the lowest cylinder speed of $0.5 \mathrm{~m}$ $\mathrm{s}^{-1}$ and increased with increasing in cylinder speed.

The machine capacity was the least at the lowest concave clearance of 20 $\mathrm{mm}$ and increased with increasing in concave clearance. This may be due to with increasing the clearance, the bulb pass easily from the concave. The machine capacity increased with increasing in moisture content. This may be due to increase in the weight bulb, as shown in figure (10).

\subsection{Required power (RP)}

The required power ranged from 938 to $1057 \mathrm{~W}$ for cylinder speed of 0.5 to $1.5 \mathrm{~m} \mathrm{~s}^{-1}$, the concave clearance of $20 \mathrm{~mm}$ to $30 \mathrm{~mm}$ and moisture content of 61.5 to $70.3 \%$ (Table 6).

The required power was influenced by the cylinder speed, concave clearance and moisture content. The required power was the least at the lowest cylinder speed of $0.5 \mathrm{~m} \mathrm{~s}^{-1}$ and increased with increasing in cylinder speed. 
The required power was the least at the lowest concave clearance of 30 $\mathrm{mm}$ and increased with decreasing in concave clearance. This may be due to with increasing the clearance, the force to loose bulb is low.

The required power increased with increased in moisture content, this due to increase in the friction force with increasing in moisture content, as shown in figure (11).

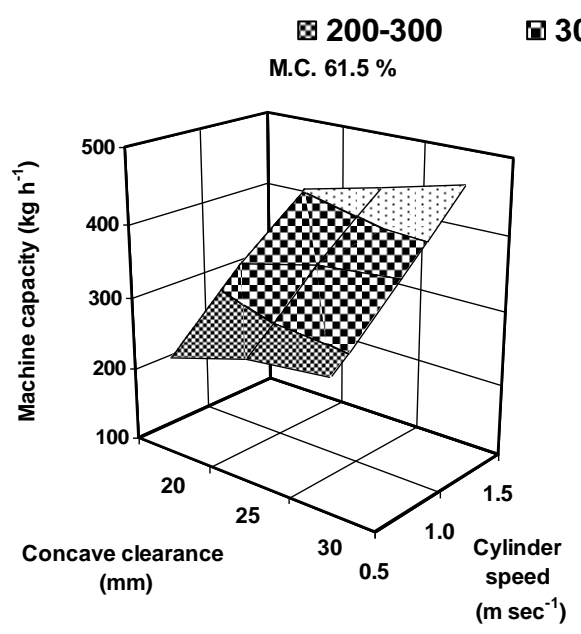

300-400 $\square$ 400-500

M.C. $70.3 \%$

Fig. (10): The effects of cylinder speed, concave clearance and
moisture content on machine capacity.

Fig. (10): The effects of cylinder speed, concave clearance and
moisture content on machine capacity.
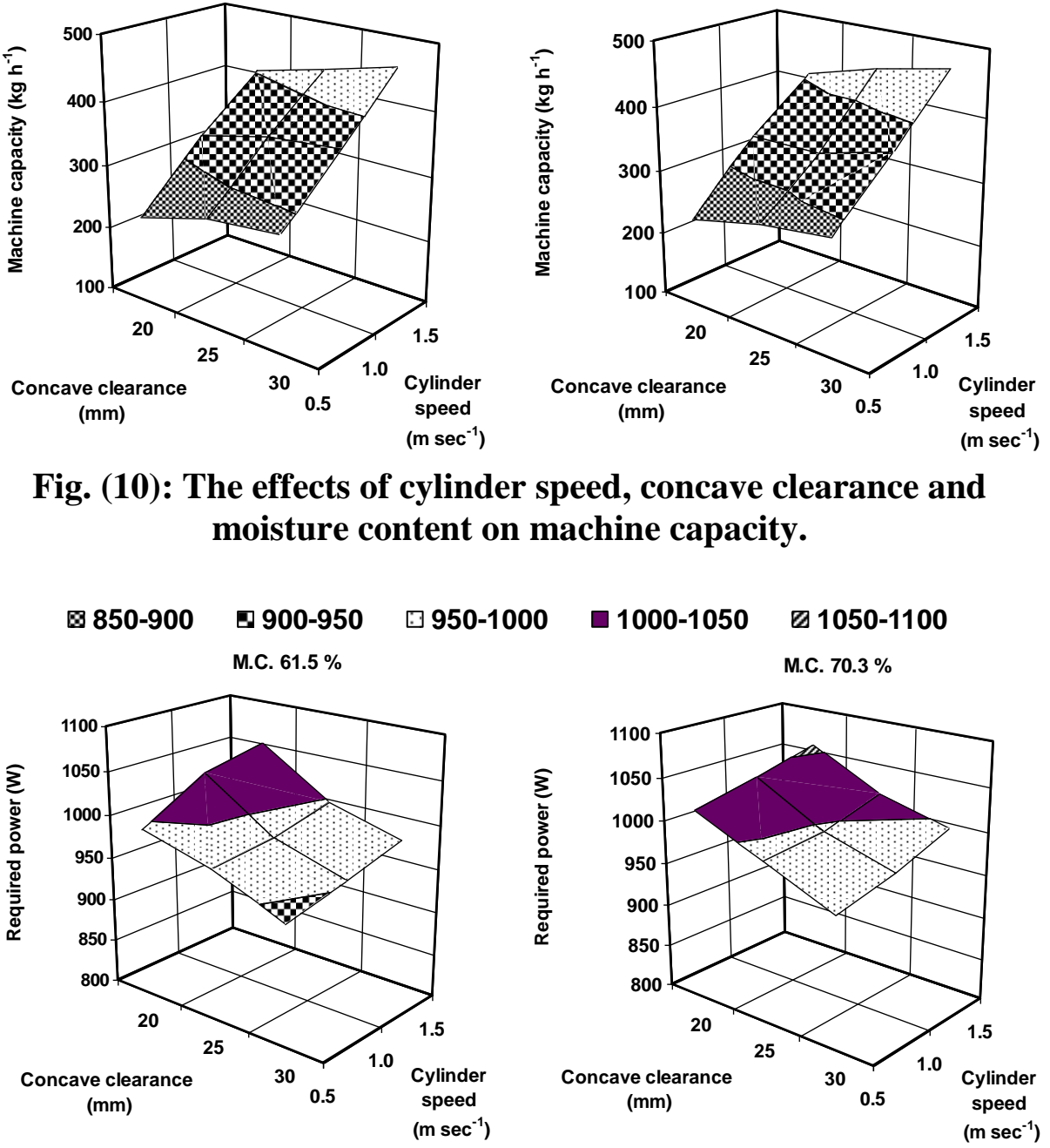

Fig. (11): The effects of cylinder speed, concave clearance and moisture content on required power. 


\subsection{Consumed energy (CE)}

The consumed energy ranged from 2.14 to $4.265 \mathrm{~kW} \mathrm{~h}$ ton $^{-1}$ for cylinder speed of 0.5 to $1.5 \mathrm{~m} \mathrm{~s}^{-1}$ and the concave clearance of $20 \mathrm{~mm}$ to $30 \mathrm{~mm}$ (Table 6). The consumed energy was influenced by the cylinder speed, concave clearance and moisture content. The consumed energy was the least at the highest cylinder speed of $1.5 \mathrm{~m} \mathrm{~s}^{-1}$ and increased with decreasing in speed. This may be due to that increasing in machine capacity with increase the speed.

The consumed energy the least at the lowest concave clearance of $30 \mathrm{~mm}$ and increased with decrease in concave clearance, this due to with increasing the clearance, the bulb passes easily from the separated unit. The consumed energy was almost the same at the moisture contents of $61.5 \%$ to $70.3 \%$., as shown in figure (12).

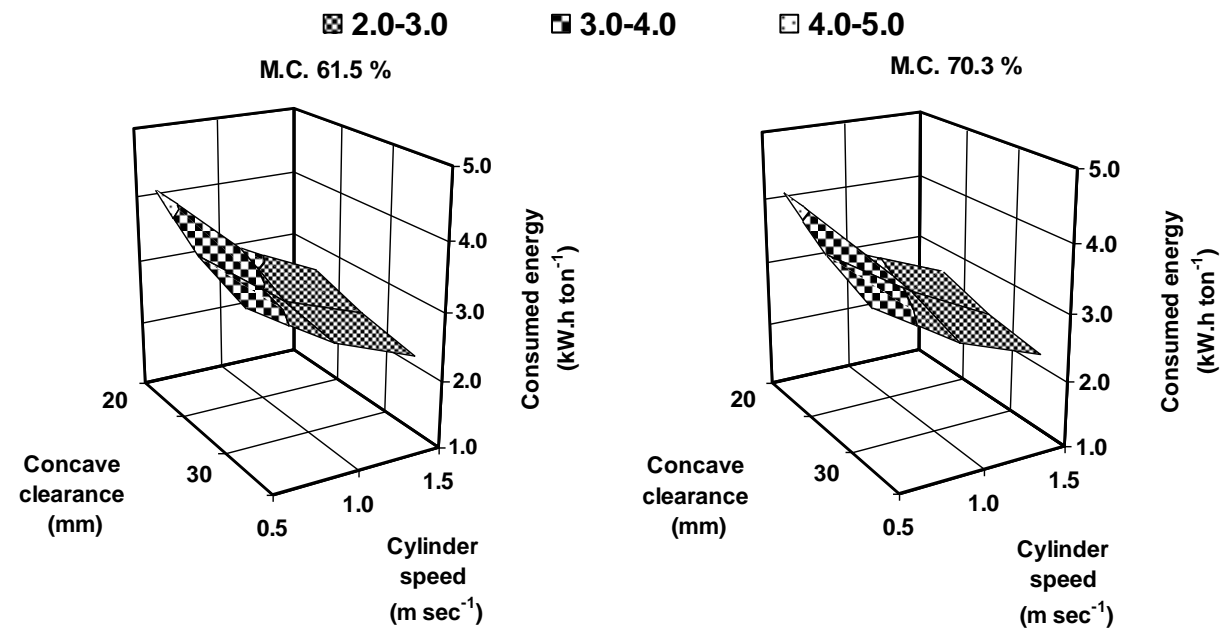

Fig. (12): The effects of cylinder speed, concave clearance and moisture content on consumed energy.

From the table (6), the most suitable working parameter of the machine that realize acceptable separation efficiency $(75.25 \%-87.8 \%)$, and low bulb damage $(5.3 \%-10.7 \%)$ were observed at combinations of cylinder speed in the range 0.5 to $1 \mathrm{~m} \mathrm{~s}^{-1}$, concave clearance between 20 and 25 $\mathrm{mm}$ and moisture content value of $61.5 \%$ or cylinder speed $=0.5 \mathrm{~m} \mathrm{~s}^{-1} /$ concave clearance $=20 \mathrm{~mm}$ or cylinder speed $=1 \mathrm{~m} \mathrm{~s}^{-1} /$ concave clearance $=20$ to $25 \mathrm{~mm}$ at moisture content value of $70.3 \%$. 
Figure (14) represents the contour plots of the response variables were used to observe, determine and predict the optimum combinations of cylinder speed, concave clearance and moisture content based on the principle of which keeps superior separation efficiency, minimum the bulb damage, highest machine capacity and lowest power.

\subsection{Costs}

From Figure (13), the separated bulb for one hour by the manual method, and developed machine are 50.5 and $326.92 \mathrm{~kg}$, and the separation costs are 100 and 30.77 L.E ton $^{-1}$ (according to 2012 local conditions) respectively. Using the developed machine increased the capacity to about 5.47 times and reduced the separation cost to about $69.23 \%$ compared with manual method.

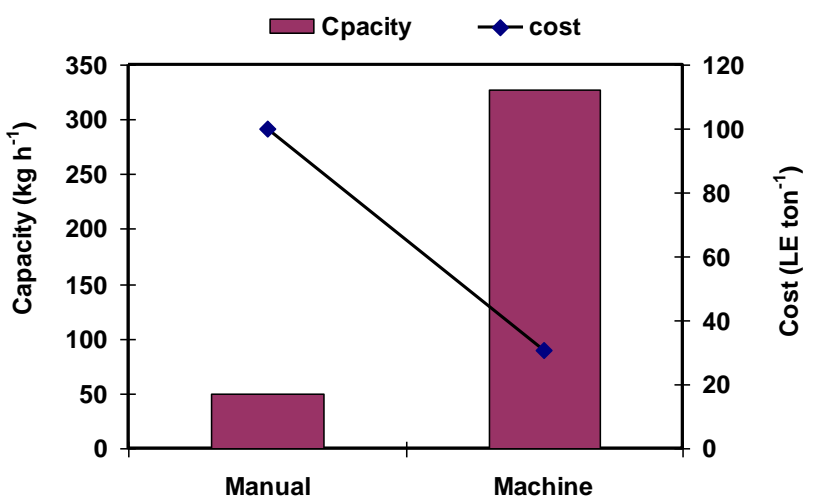

Fig. (13): Capacity and cost of separation with different methods.

\subsection{Regression models for the performance parameters}

The obtained data of table (6) for the moisture content, cylinder speed and concave clearance were used as factors affecting the values of separation efficiency, bulb damage, machine capacity, required power and consumed energy, multiple regression approach (by using SPSS software version 14) was used to derive a regression equation (20). Equation (20) expresses mathematical relation, which is linear (firstorder).

$$
\mathbf{Y}=\mathbf{a} \cdot \mathrm{MC}_{\mathrm{C}}+\mathbf{b} \cdot \mathrm{Cs}_{\mathrm{S}}+\mathbf{c} \cdot \mathrm{C}_{\mathrm{C}}+\mathbf{k}
$$

Where

$Y \quad: \quad$ The value of separation efficiency, bulb damage, machine capacity, required power and consumed energy.

$M_{C} \quad$ : $\quad$ Moisture content, $\% ;\left(61.5 \leq M_{C} \leq 70.3\right)$.

$C_{S} \quad: \quad$ Cylinder speed, $\mathrm{m} \mathrm{s}^{-1} ;\left(0.5 \leq C_{S} \leq 1.5\right)$. 

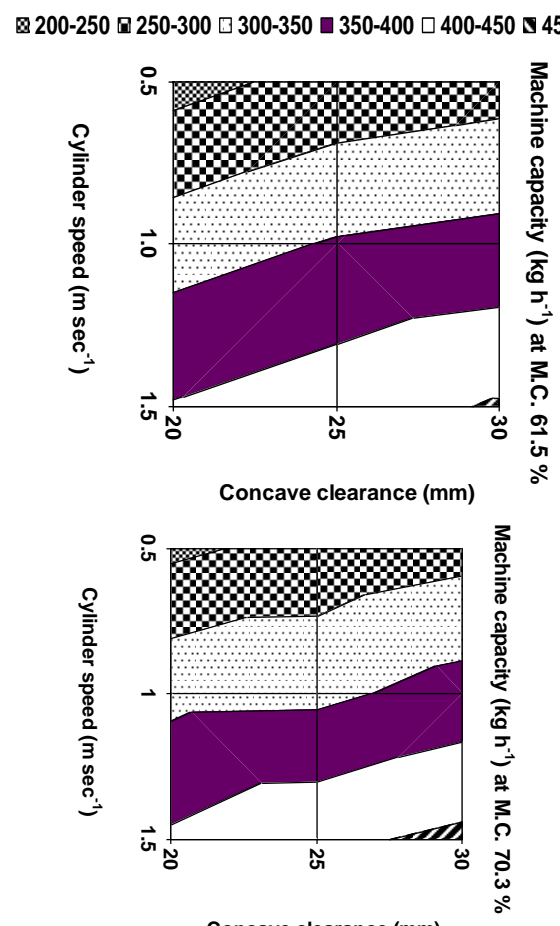

Concave clearance $(\mathrm{mm})$
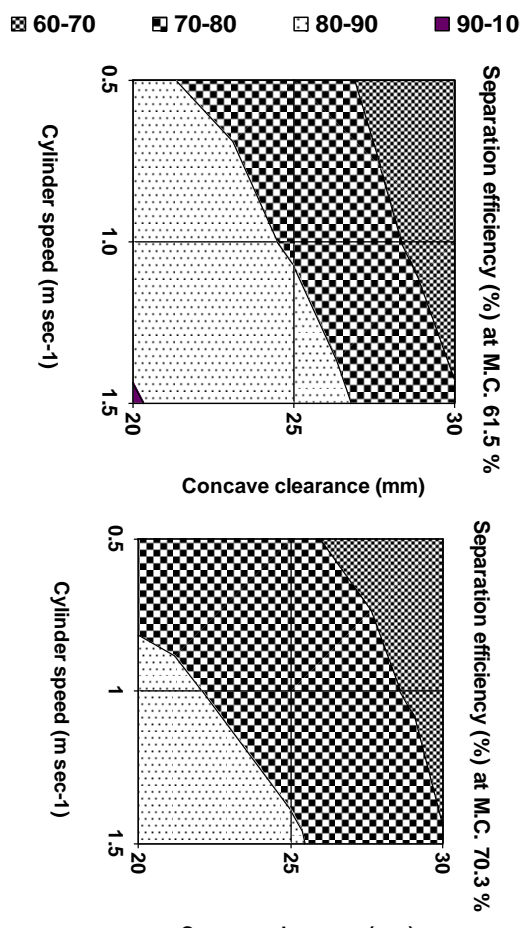

Concave clearance $(\mathrm{mm})$

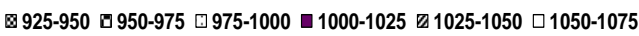

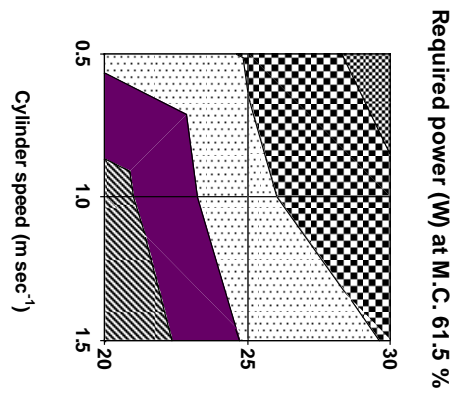

Concave clearance $(\mathrm{mm})$

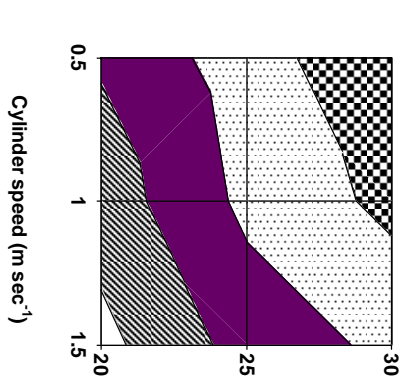

Concave clearance $(\mathrm{mm})$

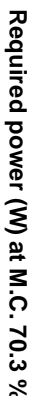

Fig. (14): the contour plots of the $P_{m}, S E, B D, R P$.
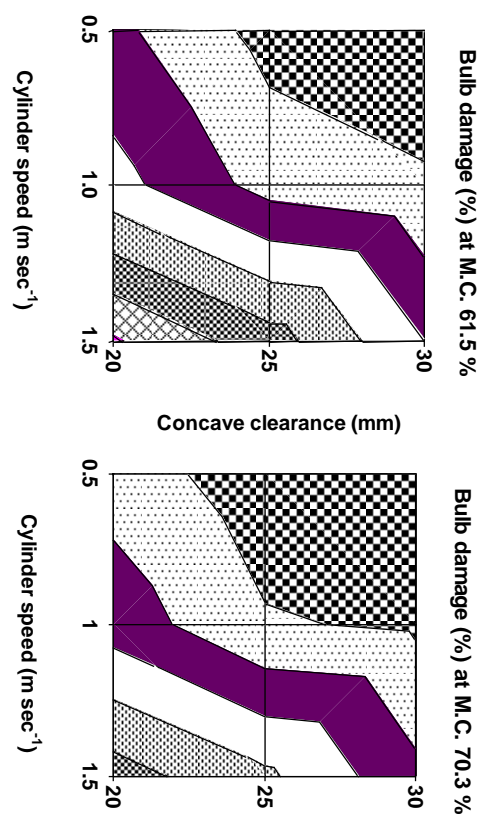

Concave clearance $(\mathrm{mm})$

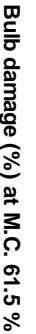

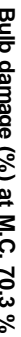


$\mathrm{C}_{\mathrm{C}} \quad:$ Concave clearance, $\mathrm{mm} ;\left(20 \leq C_{C} \leq 30\right)$

$\mathrm{a}, \mathrm{b}, \mathrm{c}$ : Empirical constants.

$\& \mathrm{k}$

The values of the empirical constants (a, b, c and k) and the coefficient of determination $\left(\mathrm{R}^{2}\right)$ of equation (20) are shown in table (7).

Table (7): The empirical constants and the coefficient of determination $\left(R^{2}\right)$ for the five performance parameters.

\begin{tabular}{|c|c|c|c|c|c|}
\hline \multirow{2}{*}{$(\mathbf{Y})$} & \multicolumn{4}{|c|}{ Empirical constant } & \multirow{2}{*}{$\mathbf{R}^{2}$} \\
\hline & a & b & c & $\mathbf{k}$ & \\
\hline Separation efficiency, SE (\%) & -0.291 & 8.87 & -1.723 & 129.56 & 0.933 \\
\hline Bulb damage, BD (\%) & -0.159 & 7.462 & -0.494 & 24.13 & 0.89 \\
\hline Machine capacity, $P_{m}\left(\mathrm{~kg} \mathrm{~h}^{-1}\right)$ & 0.372 & 170.48 & 4.436 & 41.48 & 0.995 \\
\hline Required power, $\mathbf{R P}(\mathrm{W})$ & 1.679 & 36.63 & -6.953 & 1022.3 & 0.964 \\
\hline Consumed energy, $\mathrm{CE}\left(\mathrm{kW} \cdot \mathrm{h}\right.$ ton $\left.^{-1}\right)$ & 0.002 & -1.41 & -0.062 & 5.83 & 0.957 \\
\hline
\end{tabular}

\section{CONCLUSION}

The obtained results can be summarized as follows:

1. Moisture content, cylinder speed and concave clearance affected the performance of the machine.

2. Separation efficiency and bulb damage increased with increasing in cylinder speed, but decreased with increasing in concave clearance and moisture content.

3. Machine capacity increased with increasing in cylinder speed, concave clearance and moisture content.

4. Required power increased with increasing in cylinder speed and moisture content, but decreased with increasing in concave clearance. 
5. Consumed energy increased with increasing in moisture content, but decreased with increasing in cylinder speed and concave clearance.

6. It is recommended to use the following operating variables at combinations of cylinder speed $=0.5$ to $1 \mathrm{~m} \mathrm{~s}^{-1} /$ concave clearance $=20$ to $25 \mathrm{~mm}$ and moisture content value of $61.5 \%$.

7. The empirical results obtained from experiments were used to introduce a group of contour charts and derived mathematical equation to predict the value of " $\mathrm{P}_{\mathrm{m}}, \mathrm{SE}, \mathrm{BD}, \mathrm{RP}$ and $\mathrm{CE}$ " as a function of $\mathrm{M}_{\mathrm{C}}, \mathrm{C}_{\mathrm{C}}$ and $\mathrm{C}_{\mathrm{S}}$.

8. Using the developed machine increased the capacity to about 5.47 times and reduced the separation cost to about $69.23 \%$ compared with manual method.

\section{REFERENCES}

Arnold, R. E. 1964. Experiments with rasp bar threshing drums. I: Some factors affecting performance. J. Agr. Engng. Res. (9):99-131.

ASAE Standards. 1999. Terminology for combines and grain harvesting. Standard ASAE NO: S343.3. St. Joseph, Mich. ASAE:192-196.

ASAE Standards. 1999. Moisture measurement - unground grain and seeds. Standard ASAE NO: S352.2 DEC97. St. Joseph, Mich. ASAE:567.

Chancellor, W. J. 1981. Substituting information for energy in agricultural. Trans. ASAE Paper No. 0001- 2351.

Chen, H., M. Iwasaki and H. Takeda.2004. Development of a baker's garlic seed bulb cluster separator using response surface methodology. An ASAE/CSAE Annual International Meeting. Paper Number: 041086. 
CIGR. 1999. Handbook of agricultural engineering. Volume III. Plant Production Engineering. The International Commission of Agricultural Engineering. Published by the ASAE.

Eric, O. 1976. Machinery's Hand Book. 20th ed. New York, Industrial Press .

FAOSTAT. 2010. FAO Statistical Yearbook. Agricultural production.

Halling, J. 1975. Principles of Tribology. Printed in Great Britain by Tinling (1973) Ltd, Prescot, Merseyside.

Ibrahim M. M. 2008. Determination of dynamic coefficient of friction for some materials for feed pellet under different values of pressure and temperature. Misr J. Ag. Eng., 25(4):1389-1409.

Iwasaki, M., A. Ishihara and Ki-chul Kim. 1992. Mechanization of Baker's garlic planting in sandy field. ASAE Paper No. 921507. St. Joseph, Mich. ASAE.

Karababa, E. 2006. Physical properties of popcorn kernels. J. Food Eng., 72, 100-107.

Khurmi, R. S. and J. K.Gupta. 2005. Theory of Machines. New Delhi: Eurasia Publishing house. 315.

Matlob, A. N. and A. M. Khalel. 1986. Effect of planting dates, plant spacing and clove size on vegetative growth and bulbing of garlic (ALLIUM SATIVUM L.). Iraqi J. Agric. Sc. zanco 4(3): 35-50.

Mohsenin, N. N. 1986. Physical properties of plant and animal materials. 2nd ed. Gordon and Breach Sc. Publishers

Nourai, A. H. 1994. Effect of planting methods and seed rates on yield, yield components and quality of garlic (ALLIUM SATIVUM L.) in the Sudan. Acta hort. 358: 359-364. 
Shigley, J. E 2008. Mechanical engineering design. S.I (metric) ed. McGraw-Hill, New York, USA:909.

Srivastava, A. K., C. E. Goering, R. P. Rohrbach and D. R. Buckmaster. 2006. Engineering principles of agricultural machines. St. Joseph, Mich.: ASAE.

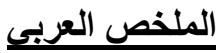

\section{تطوير آلة لتفصيص الثوم: 1 ـ جهاز الفصل}

\section{* محمد محمود إبراهيم}

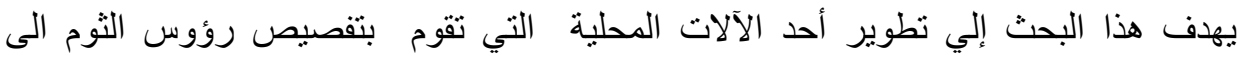

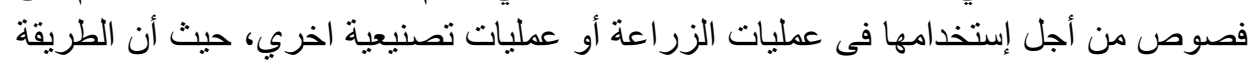

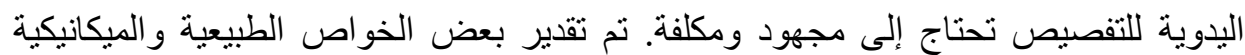

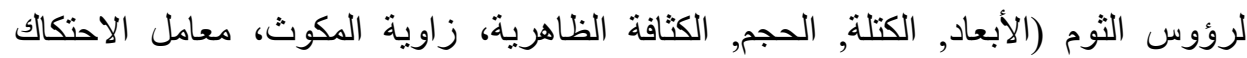

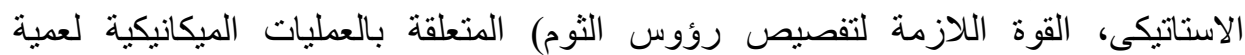

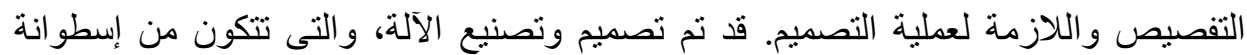

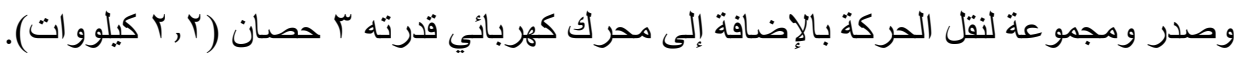

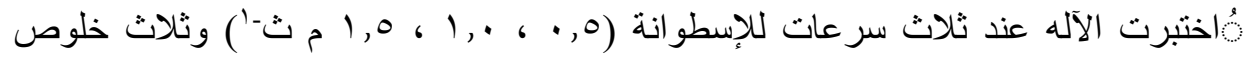

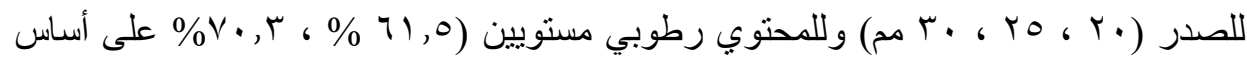

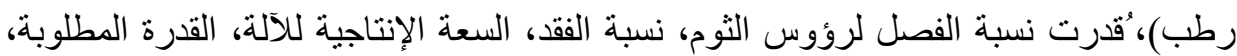

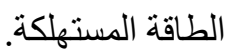

بينت الاراسة العلاقات المتداخلة التالية: ! كفاءة الفصل تزداد مع زيادة سرعة الإسطو انة، وتقل مع زيادة خلوص الصدر و المحتوي

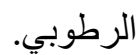

r. نسبة الفقد تزداد مع زيادة سرعة الإسطوانة، وتقل مع زيادة خلوص الصدر و المحتوي الرطوبي.

r. إنتاجية الآلة تزداد مع زيادة كلا من سرعة الإسطو انة، خلوص الصدر، المحتوي الرطوبي.

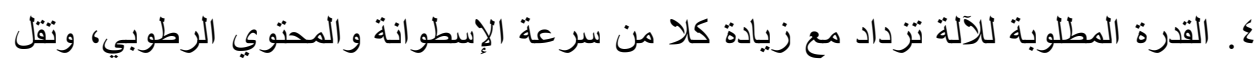
بزيادة خلوص الصدر. 
○. الطاقة المستهلكة تزداد بزيادة المحتوي الرطوبي، وتقل بزيادة كلا من سرعة الإسطوانة وخلوص الصدر. T. ينصح بتشغيل الآلة على مدي من السرعات ه, • الى ا م ثـ-' وخلوص للصدر فى المدي

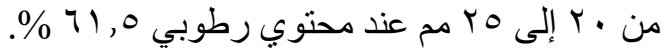

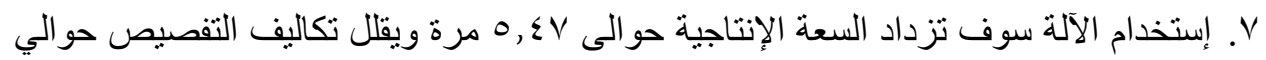

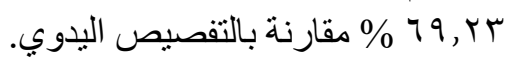

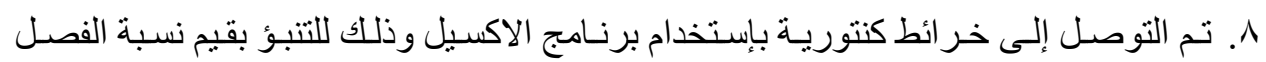

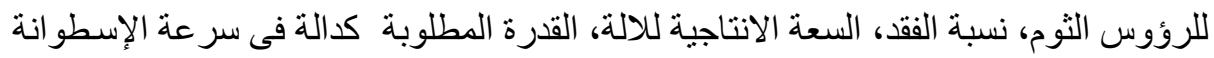
وخلوص الصدر والمحتوي الرطوبي.

9. كذلك تم التوصل إلي معادلة بطريقة الإنحدار الخطي بقيم نسبة الفصل للرؤوس الثوم، نسبة

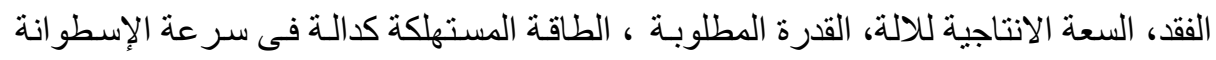
وخلوص الصدر و المحتوي الرطوبي. 